\title{
UJI FUNGSIONALITAS (BLACKBOX TESTING) SISTEM INFORMASI LEMBAGA SERTIFIKASI PROFESI (SILSP) BATIK DENGAN APPPERFECT WEB TEST DAN UJI PENGGUNA
}

\author{
Dhega Febiharsa $^{1}$, I Made Sudana ${ }^{2}$, Noor Hudallah ${ }^{3}$ \\ ${ }^{1}$ IKIP Veteran Jawa Tengah \\ ${ }^{2,3}$ Universitas Negeri Semarang \\ febiharsa@gmail.com ${ }^{1}$ \\ sudana@mail.unnes.ac.id ${ }^{2}$ \\ noorhudallah@mail.unnes.ac.id ${ }^{3}$
}

Diterima: Desember 2018. Disetujui: Desember 2018. Dipublikasikan: Januari 2019

\begin{abstract}
ABSTRAK
Sistem Informasi dalam sebuah organisasi memiliki peranan yang cukup penting dalam memberikan informasi kepada manajemen dalam rangka mengendalikan berbagai proses yang kompleks dalam sebuah organisasi. Implementasi sistem informasi pada Lembaga Sertifikasi Profesi Batik, dapat membantu manajemen LSP Batik dalam mengendalikan proses dalam organisasi, mulai dari peserta, asesor, Tempat Uji Kompetensi, hingga penjadwalan uji kompetensi. Sistem informasi yang dirancang bangun haruslah melalui suatu pengujian sebelum digunakan. Pengujian sistem informasi dilakukan untuk mengetahui layak tidaknya aplikasi untuk digunakan oleh pengguna. Penelitian ini bertujuan untuk melakukan serangkaian uji terhadap sistem informasi yang telah dirancang bangun. Metode yang digunakan adalah eksperimental, menggunakan aplikasi AppPerfect Web Test dan instrumen kuesioner uji Fungsional (Black Box Testing) yang diberikan kepada pengguna. Tujuan dari penelitian ini, untuk mengetahui sejauh mana kedua metode pengujian ini dapat reliabel dalam menguji sistem informasi lembaga sertifikasi profesi yang dibangun. Berdasarkan analisa yang dilakukan, aplikasi AppPerfect Web Test sejalan dengan hasil uji fungsi oleh pengguna. Dengan kata lain pengujian fungsionalitas dapat dilakukan dengan pengguna maupun dengan aplikasi AppPerfect Web Test, atau keduanya.
\end{abstract}

Kata kunci: Uji Fungsionalitas, AppPerfect Web Test, Sistem Informasi Lembaga Sertifikasi Profesi.

\begin{abstract}
Information systems in an organization have an important role in providing information to management in order to control various complex processes within an organization. The implementation of information systems in the Batik Professional Certification Institute, can help the management of Batik LSP in controlling processes in organizations, ranging from participants, assessors, Competency Test Places, to scheduling competency tests. Information systems designed to build must be through a test before use. Information system testing is carried out to determine whether or not the application is suitable for use by users. This study aims to conduct a series of tests on information systems that have been designed to build. The method used is experimental, using the AppPerfect Web Test application and the Functional Test questionnaire (Black Box Testing) instrument provided to users. The purpose of this study, to determine the extent to which these two test methods can be reliable in testing the information system of professional certification institutions that are built. Based on the analysis carried out, the AppPerfect Web Test application is in line with the results of the function test by the user. In other words, functional testing can be done by users or with the AppPerfect Web Test application, or both.
\end{abstract}


Keywords: Functional Test, AppPerfect Web Test, Professional Certification Institution Information System.

\section{PENDAHULUAN}

Simanjuntak (2010), menyatakan bahwa Black-Box Testing merupakan pengujian perangkat lunak yang merupakan tes fungsionalitas dari aplikasi yang tidak mengacu pada struktur internal atau tidak membutuhkan pengetahuan khusus pada kode program aplikasi dan pengetahuan pengguna. Ujicoba Black-Box dilakukan untuk menemukan kesalahan dalam beberapa kategori yaitu: (1) Fungsi-fungsi yang hilang atau salah; (2) Kesalahan desain antarmuka (interface) atau tampilan; (3) Kesalahan dalam struktur data atau akses database ekternal; (4) Kesalahan performa; dan (5) Kesalahan inisialisasi dan terminasi.

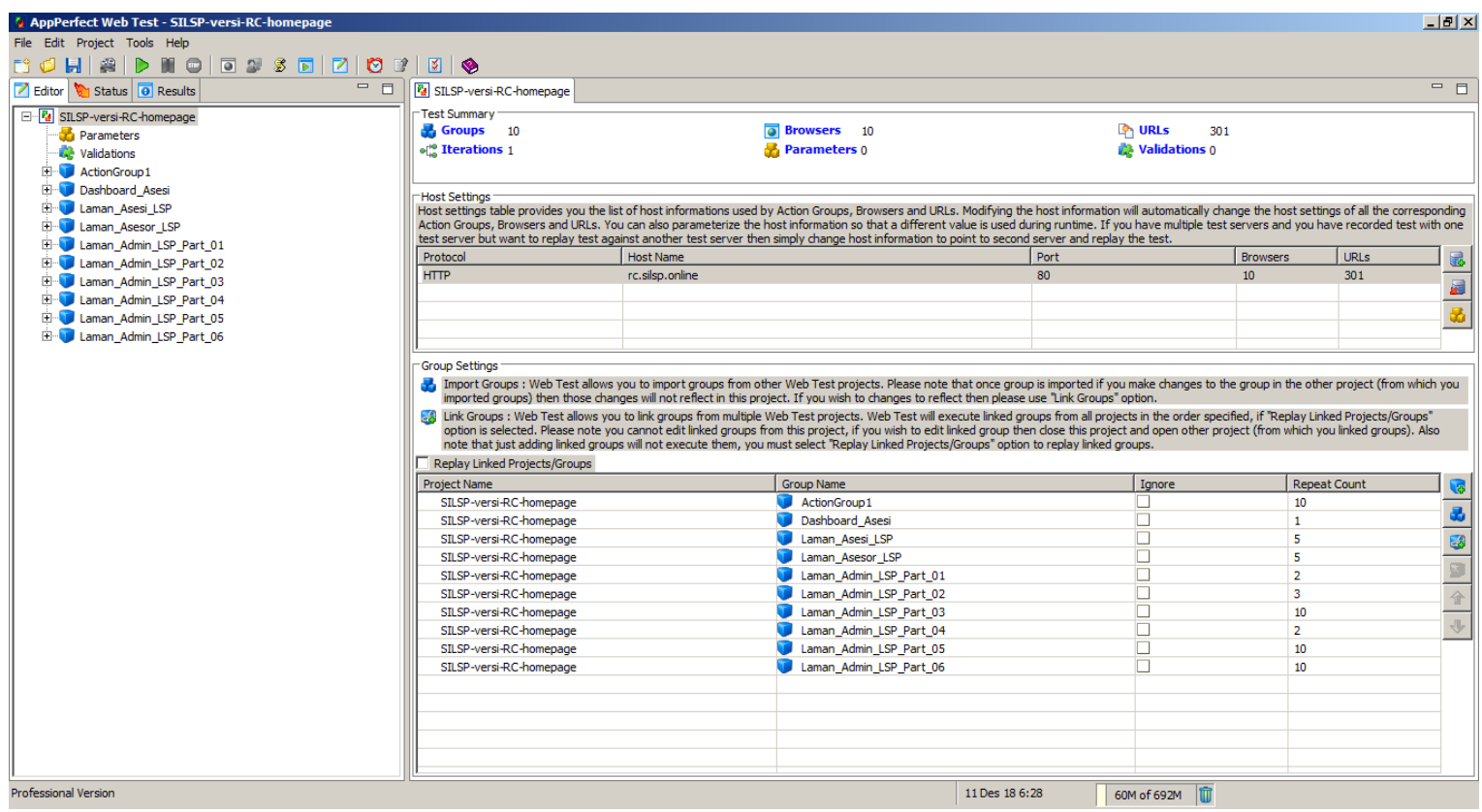

Gambar 1. Antarmuka aplikasi AppPerfect Web Test 15.0.0

pemrograman. Pengujian berada di ranah spesifikasi dan persyaratan yang seharusnya. Pengujian ini menggunakan deskripsi eksternal perangkat lunak termasuk spesifikasi, persyaratan dan desain untuk menurunkan uji kasus (pengujian). Umumnya tes ini merupakan tes fungsional, namun ada juga berupa tes non fungsional. Perancang uji memilih input yang valid dan tidak valid serta menentukan keluaran (output) yang benar, tanpa harus mengetahui struktur internal dari yang diuji. Metode ini dapat diterapkan pada semua tingkat pengujian perangkat lunak seperti, unit, fungsional, integrasi, sistem dan penerimaan
Sedangkan Blackbox Testing menurut Wikipedia (2012) adalah metode pengujian perangkat lunak yang meneliti fungsi (Functional Testing) dari aplikasi tanpa melihat ke dalam struktur internal atau kinerja aplikasi. Metode uji ini dapat diterapkan untuk hampir setiap tingkat pengujian perangkat lunak seperti Unit, integrasi, sistem dan penerimaan. Sedangkan Pressman (2001: 459) menyatakan bahwa pengujian black-box, juga disebut pengujian perilaku, yang berfokus pada persyaratan fungsional perangkat lunak. Black-box testing memungkinkan programmer perangkat lunak untuk memberikan set 
kondisi input yang sepenuhnya akan menjalankan semua persyaratan fungsional untuk sebuah program. Sejalan dengan dua pendapat tersebut, Williams (2010: 36) menyatakan pengujian blackbox atau disebut uji fungsional adalah pengujian yang mengabaikan mekanisme internal sistem atau komponen dan hanya berfokus pada output yang dihasilkan dalam menanggapi input yang dipilih dan kondisi eksekusi. Sehingga dapat disimpukan bahwa blackbox testing merupakan pengujian yang berorientasi pada fungsionalitas yaitu perilaku dari perangkat lunak atas input yang diberikan pengguna sehingga mendapatkan/ menghasilkan output yang diinginkan tanpa melihat proses internal atau kode program yang dieksekusi oleh perangkat lunak.

Adapun Blackbox Testing menurut softwaretestinghelp.com (2018), dibagi menjadi dua jenis, yaitu: (1) Functional Testing, dimana jenis ini berkaitan dengan persyaratan fungsional atau spesifikasi aplikasi. Beberapa jenis Pengujian Fungsional utama adalah: (a) Smoke Testing; (b) Sanity Testing; (c) Integration Testing; (d) System Testing; (e) Regression Testing; dan (f) User Acceptance Testing; dan (2) Non-Functional Testing, dimana terlepas dari fungsionalitas persyaratan, ada beberapa aspek non-fungsional yang perlu diuji untuk meningkatkan kualitas dan kinerja aplikasi, yang meliputi: (a) Usability Testing; (b) Load Testing; (c) Performance Testing; (d) Compatibility Testing; (e) Stress Testing; dan (f) Scalability Testing.

Aplikasi perangkat lunak "Sistem Informasi Uji Kompetensi Lembaga Sertifikasi Profesi (LSP) Batik" akan diuji dengan menggunakan teknik black-box testing dengan aplikasi AppPerfect Web Test, untuk mengetahui dan memastikan fungsi dari fiturfitur aplikasi yang dibangun dapat bekerja dengan baik, sehingga layak untuk digunakan. Selanjutnya akan dibandingkan dengan hasil uji fungsi menurut pengguna yang sebenarnya.
Analisis fungsional merupakan analisis atas hasil dari uji fungsi (Black Box Testing) yang telah dijabarkan sebelumnya. Pada uji fungsionalitas dilakukan dengan bantuan perangkat lunak AppPerfect Web Test versi 15.0.0 untuk melakukan uji fungsi laman web, tombol-tombol, formulirformulir dan tautan-tautan. Selanjutnya dengan analisis statistik deskriptif, akan dideskripsikan hasil dari pengujian fungsional yang dilakukan. AppPerfect Web Test menurut appperfect.com (2018), adalah perangkat lunak pengujian fungsionalitas dan pengujian regresi web terpadu yang sepenuhnya otomatis. Aplikasi apa pun yang dapat diakses melalui browser Web dapat diuji. AppPerfect Functional Tester dirancang untuk para pengembang dan juga profesional QA. Hasil luaran dari aplikasi ini selanjutnya akan dianalisis, dimana analisis ini akan menjelaskan seberapa jauh aplikasi yang dirancang bangun dapat berfungsi atau tidaknya, dan apakah fungsinya dapat dipahami oleh pengguna atau tidak. Analisis ini juga dilakukan menggunakan instrumen kuesioner uji coba fungsional oleh pengguna (Asesi, Asesor, dan Administrator).

\section{METODE PENELITIAN}

Penelitian ini menggunakan metode ekperimen, dimana penelitian eksperimen menurut Sugiono (2016:107), metode eksperimen adalah metode penelitian yang digunakan untuk mencari pengaruh perlakuan tertentu terhadap yang lain dengan kondisi yang terkendali. Penelitian dilakukan dengan dua perlakuan terhadap subyek penelitian, yaitu aplikasi Sistem Informasi Lembaga Sertifikasi Profesi Batik. Penelitian dilakukan dengan menguji sistem informasi dengan aplikasi AppPerfect Web Test 15.0.0 untuk mengetahui keberfungsian fitur, tombol, dan tautan pada sistem informasi (subyek) penelitian. Berikutnya dilakukan uji fungsi oleh tiga orang praktisi bidang 
teknologi informasi dalam hal ini adalah tiga Dosen Program Studi Pendidikan Informatika, IKIP Veteran Jawa Tengah.

Pada uji fungsi dengan AppPerfect

Web Test, dilakukan dengan 10 kali iterasi atau perulangan untuk setiap laman, yaitu laman admin, laman asesi, dan laman asesor. Aplikasi AppPerfect Web Test, akan menghasilkan laporan dari hasil pengujian tersebut.

Berikutnya, sistem informasi dinilai oleh pengguna dengan instrumen uji fungsi yang diisi berdasarkan pengamatan dan percobaan/ tindakan oleh praktisi teknologi informasi yang berperan sebagai pengguna asesi, asesor dan administrator Lembaga Sertifikasi Profesi Batik.

Hasil uji fungsi dengan AppPerfect Web Test dan uji fungsi oleh pengguna ini selanjutnya dianalisa untuk mengetahui seberapa efektif pengujian masing-masing untuk mengetahui seberapa berfungsi aplikasi yang dibangun. Analisis menggunakan Uji $\mathrm{T}$, untuk mengetahui perbedaan keduanya. Sebelumnya data dilakukan normalisasi terlebih dahulu agar dapat menghasilkan analisa yang valid. Normalisasi ini dilakukan karena adanya perbedaan antara pengujian dengan AppPerfect Web Test yang berskala ordinal 4 dengan pengujian oleh pengguna yang berskala ordinal 5 .

\section{HASIL DAN PEMBAHASAN}

\section{Uji Fungsionalitas (Blackbox) laman Asesi/ Peserta dengan AppPerfect Web Test}

Uji keberfungsian (blackbox testing) dilakukan dengan bantuan perangkat lunak AppPerfect Web Test versi 15.0.0, yang dilakukan dengan 10 iterasi atau perulangan dengan tiga kondisi yaitu: (1) Successful atau sukses; (2) Failed atau gagal; (3) Timed Out atau waktu koneksi habis; dan (4) Not Played atau tidak dijalankan/ dimainkan. Adapun perangkat komputer yang digunakan dalam uji coba ini memiliki spesifikasi sebagai berikut:

Tabel 1. Spesifikasi Komputer yang digunakan untuk Uji Keberfungsian dengan perangkat lunak AppPerfect Web Test

\begin{tabular}{|c|c|}
\hline Spesifikasi & Ukuran/ Volume/ Versi \\
\hline Prosesor & $\begin{array}{l}\text { Intel Core i3 } 21203,30 \\
\mathrm{GHz}\end{array}$ \\
\hline Memori & $4 \mathrm{~GB}$ \\
\hline Penyimpanan & $500 \mathrm{~GB}$ \\
\hline Sistem Operasi & $\begin{array}{l}\text { Windows } 7 \text { Profesional } \\
\text { 64-bit }\end{array}$ \\
\hline Browser & $\begin{array}{l}\text { Google Chrome versi } \\
68.0 .3440 .106 \text { (64-bit) }\end{array}$ \\
\hline
\end{tabular}

Percobaan pada laman Asesi yang dilakukan dengan $10 \mathrm{kali}$ percobaan/ iterasi tersebut menghasilkan data sebagai berikut:

Tabel 2. Rekapitulasi hasil uji fungsionalitas laman Asesi dengan aplikasi AppPerfect Web Test

\begin{tabular}{lccc}
\hline \multicolumn{1}{c}{ Result } & Ordinal & Frequency & Percent \\
\hline Successful & 1 & 1.371 & $99,35 \%$ \\
Failed & 2 & 9 & $0,65 \%$ \\
Timed Out & 3 & 0 & $0 \%$ \\
Not Played & 4 & 0 & $0 \%$ \\
\hline TOTAL & & 1.380 & $100,00 \%$ \\
\hline
\end{tabular}

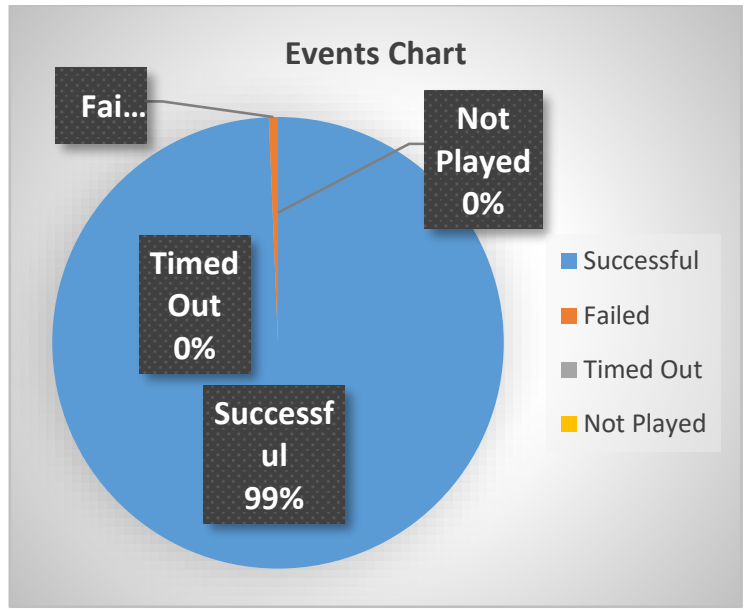

Gambar 2. Grafik hasil uji fungsionalitas (blackbox) laman Asesi dari output perangkat lunak AppPerfect Web Test

Berdasarkan data di atas, fungsionalitas dengan nilai berhasil (Successful) didapatkan nilai $99 \%$ atau dengan kata lain menu-menu, tombol-tombol, form (isian) dan link (tautan) pada laman asesi Sistem Informasi Lembaga 
Sertifikasi Profesi (LSP) dapat berfungsi dengan sangat baik. Sehingga secara teknis, dapat dikatakan laman ini layak digunakan.

\section{Uji Keberfungsian (Blackbox) laman Asesor dengan AppPerfect Web Test}

Pada pengujian laman asesor dengan perangkat lunak AppPerfect Web Test, yang dilakukan dengan 10 iterasi atau perulangan dengan tiga kondisi, seperti halnya pada laman asesi yaitu: (1) Successful; (2) Failed; (3) Timed Out; dan (4) Not Played. Adapun perangkat komputer yang digunakan dalam uji coba ini adalah perangkat yang sama dengan perangkat yang digunakan pada uji blackbox Web Test laman asesi.

Percobaan pada laman Asesor yang dilakukan dengan 10 kali percobaan atau iterasi tersebut menghasilkan data sebagai berikut:

Tabel 3. Rekapitulasi hasil uji fungsionalitas laman Asesor dengan aplikasi AppPerfect Web Test

\begin{tabular}{lccc}
\hline \multicolumn{1}{c}{ Result } & Ordinal & Frequency & Percent \\
\hline Successful & 1 & 814 & $95,76 \%$ \\
Failed & 2 & 14 & $1,88 \%$ \\
Timed Out & 3 & 14 & $1,88 \%$ \\
Not Played & 4 & 4 & $0,47 \%$ \\
\hline TOTAL & & 850 & $100,00 \%$ \\
\hline
\end{tabular}

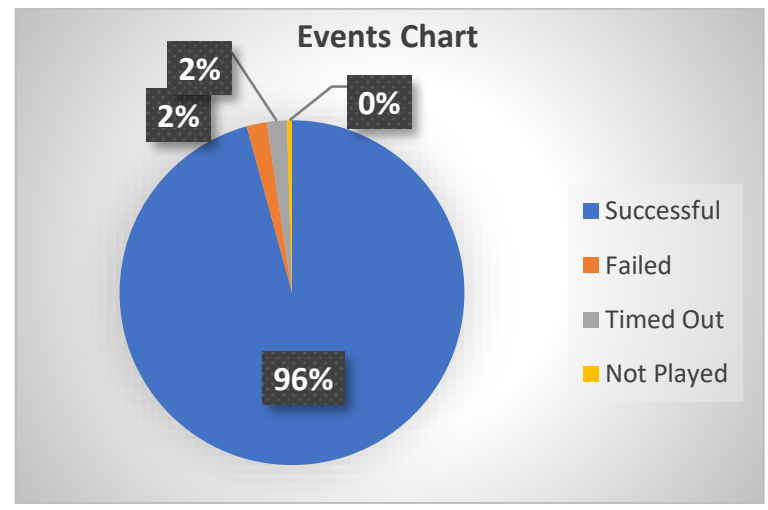

Gambar 3. Grafik hasil uji fungsionalitas (blackbox) laman Asesor dari output perangkat lunak AppPerfect Web Test

Berdasarkan data di atas, fungsionalitas dengan nilai berhasil (Successful) didapatkan nilai $96 \%$, kegagalan hanya sebesar $2 \%$, dan timed out sebesar $2 \%$. Hal ini terjadi dikarenakan koneksi internet atau browser yang tidak merespon perintah aplikasi AppPerfect Web Test. Dengan nilai keberhasilan $96 \%$ ini, dapat dikatakan menumenu, tombol-tombol, form (isian) dan link (tautan) pada laman asesi Sistem Informasi Lembaga Sertifikasi Profesi (LSP) dapat berfungsi dengan baik. Sehingga secara teknis, dapat dikatakan laman ini layak digunakan.

\section{Uji Keberfungsian (Blackbox) laman Adminstrator dengan AppPerfect Web Test}

Pada pengujian laman Administrator dengan perangkat lunak AppPerfect Web Test, yang dilakukan dengan 10 iterasi atau perulangan dengan kritreia kondisi yaitu: (1) Successful; (2) Failed; (3) Timed Out; dan (4) Not Played menggunakan perangkat komputer yang sama seperti yang digunakan pada uji blackbox Web Test laman asesi dan asesor.

Percobaan pada laman Administrator yang dilakukan dengan 10 kali percobaan atau iterasi tersebut menghasilkan data sebagai berikut:

Tabel 4. Rekapitulasi hasil uji fungsionalitas laman Administrator dengan aplikasi AppPerfect Web Test

\begin{tabular}{lccc}
\hline \multicolumn{1}{c}{ Result } & Ordinal & Frequency & Percent \\
\hline Successful & 1 & 4.626 & $99,06 \%$ \\
Failed & 2 & 20 & $0,43 \%$ \\
Timed Out & 3 & 24 & $0,51 \%$ \\
Not Played & 4 & 0 & $0,00 \%$ \\
\hline TOTAL & & 4.670 & $100,00 \%$ \\
\hline
\end{tabular}




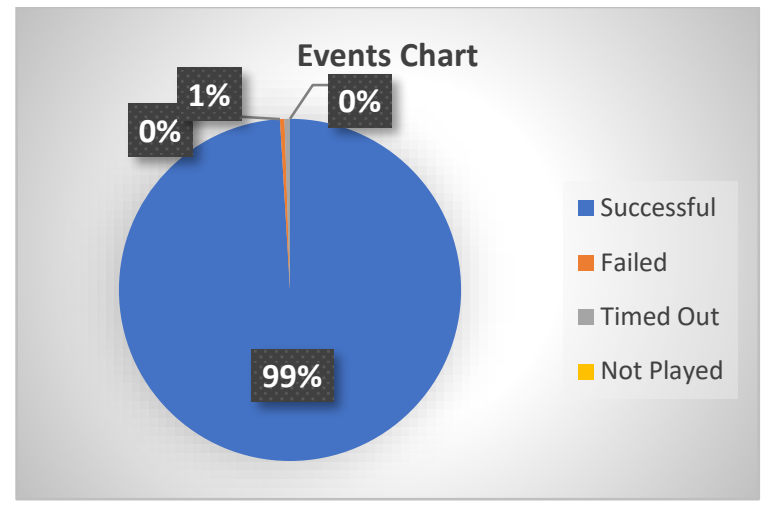

Gambar 4. Grafik hasil uji fungsionalitas (blackbox) laman

Administrator dari output perangkat lunak AppPerfect Web Test

Berdasarkan data di atas, fungsionalitas dengan nilai berhasil (Successful) didapatkan nilai 99,06 \%, kegagalan hanya sebesar $0,43 \%$, dan timed out sebesar $0,51 \%$. Hal ini terjadi dikarenakan koneksi internet atau browser yang tidak merespon perintah aplikasi AppPerfect Web Test. Dengan nilai keberhasilan 99,06\% ini, dapat dikatakan menu-menu, tombol-tombol, form (isian) dan link (tautan) pada laman administrator Sistem Informasi Lembaga Sertifikasi Profesi (LSP) dapat berfungsi dengan baik. Sehingga dapat dikatakan laman ini layak digunakan.

\section{Uji Fungsionalitas oleh Pengguna}

Pengujian blackbox untuk laman Dashboard Asesi dilakukan dengan instrumen uji keberfungsian (blackbox) dengan 94 item butir pertanyaan tentang komponen atau bagian-bagian laman Asesi yang menghasilkan analisis deskriptif. Berdasarkan hasil analisis yang dilakukan, didapatkan rata-rata nilai skor pengujian dari Rater 1 adalah 4.52, penilaian Rater 2 adalah 3,64 dan penilaian Rater 3 adalah 4.94. Bila merujuk pada Kriteria Interpretasi yang telah ditentukan sebelumnya, dapat disimpulkan bahwa laman Dashboard Asesi "Sistem Informasi Uji Kompetensi Lembaga Sertifikasi Profesi (LSP) Batik" ini layak dan dapat digunakan, karena memiliki nilai skor rata-rata di atas 3,01.
Hasil analisis data menunjukkan bahwa Rater 1 menyatakan 1,06\% komponen laman asesi cukup sesuai, 45,74\% komponen laman asesi sesuai, dan 53,19\% komponen laman asesi sangat sesuai. Rater 2 menyatakan 6,38 \% komponen laman asesi kurang sesuai, 38,30 \% komponen laman asesi cukup sesuai, 40,43\% komponen laman sesuai, dan 14,89\% komponen sangat sesuai. Sedangkan Rater 3 menyatakan 6,38\% komponen laman asesi sesuai, dan 93,62 \% komponen laman asesi sangat sesuai.

Tabel 5. Rekapitulasi hasil uji fungsionalitas laman Asesi oleh pengguna

\begin{tabular}{lccccc}
\hline Penilaian & Ordinal & Rater1 & Rater2 & Rater3 & Avg. \\
\hline Sangat & 5 & 53,19 & 14,89 & 93,62 & 53,90 \\
$\begin{array}{l}\text { Sesuai } \\
\text { Sesuai }\end{array}$ & 4 & 45,74 & 40,43 & 6,38 & 30,85 \\
$\begin{array}{l}\text { Cukup } \\
\text { Sesuai }\end{array}$ & 3 & 1,06 & 38,30 & 0 & 13,12 \\
$\begin{array}{l}\text { Kurang } \\
\text { Sesuai }\end{array}$ & 2 & 0 & 6,38 & 0 & 2,13 \\
$\begin{array}{l}\text { Tidak } \\
\text { Sesuai }\end{array}$ & 1 & 0 & 0 & 0 & 0,00 \\
\hline
\end{tabular}

Pengujian blackbox untuk laman Dashboard Asesor oleh pengguna dilakukan dengan instrumen uji keberfungsian (blackbox) pengguna dengan 49 item butir pertanyaan tentang komponen atau bagianbagian laman Asesor yang menghasilkan data analisis deskriptif. Rata-rata nilai skor pengujian dari Rater 1 adalah 4,43, rata-rata penilaian Rater 2 adalah 4,10, dan penilaian Rater 3 adalah 4,73. Bila dikaitkan dengan Kriteria Interpretasi yang telah ditentukan sebelumnya, dapat disimpulkan bahwa laman Dashboard Asesor "Sistem Informasi Uji Kompetensi Lembaga Sertifikasi Profesi (LSP) Batik" ini telah layak dan dapat digunakan, karena memiliki nilai skor penilaian rata-rata di atas 3,01.

$$
\text { Hasis analisis data, Rater } 1
$$
menyatakan 57,14 \% komponen laman Dashboard Asesor telah sesuai, dan 42,86 \% telah sangat sesuai. Rater 2 menyatakan 2,04 $\%$ komponen laman kurang sesuai, 18,37 \% komponen laman cukup sesuai, 46,94\% komponen laman telah sesuai, dan 32,65\% 
komponen laman sangat sesuai. Sedangkan Rater 3 menyatakan bahwa 4,08 \% komponen laman Asesor tidak sesuai, 10,20 $\%$ komponen laman asesor sesuai, dan 85,71 $\%$ komponen laman asesor sangat sesuai.

Tabel 6. Rekapitulasi hasil uji fungsionalitas laman Asesor oleh pengguna

\begin{tabular}{lccccc}
\hline Penilaian & Ordinal & Rater1 & Rater2 & Rater3 & Avg. \\
\hline Sangat & 5 & 42,86 & 32,65 & 85,71 & 53,74 \\
Sesuai & & & & & \\
Sesuai & 4 & 57,14 & 46,94 & 10,20 & 38,09 \\
$\begin{array}{l}\text { Cukup } \\
\text { Sesuai }\end{array}$ & 3 & 0 & 18,37 & 0 & 6,12 \\
$\begin{array}{l}\text { Kurang } \\
\text { Sesuai }\end{array}$ & 2 & 0 & 2,04 & 0 & 0,68 \\
$\begin{array}{l}\text { Tidak } \\
\text { Sesuai }\end{array}$ & 1 & 0 & 0 & 4,08 & 1,36 \\
\hline
\end{tabular}

Pengujian keberfungsian (blackbox) oleh pengguna untuk laman Dashboard Administrator dilakukan dengan instrumen uji keberfungsian (blackbox) dengan 149 item butir pertanyaan tentang komponen atau bagian-bagian laman Administrator yang menghasilkan data analisis deskriptif. Ratarata nilai skor pengujian dari Rater 1 adalah 4.96, Rater 2 adalah 3,61, sedangkan Rater 3 adalah 4,95. Bila dihubungkan dengan Kriteria Interpretasi yang telah ditentukan sebelumnya, dapat disimpulkan bahwa laman Dashboard Administrator "Sistem Informasi Uji Kompetensi Lembaga Sertifikasi Profesi (LSP) Batik" ini telah layak untuk digunakan, karena memiliki nilai skor penilaian rata-rata di atas 3,01.

Berdasarkan output aplikasi PSPP tersebut, Rater 1 menyatakan komponen laman administrator terdapat 3,57\% sesuai, dan komponen laman administrator $96,43 \%$ sangat sesuai. Rater 2 menyatakan komponen laman administrator terdapat 5,53\% kurang sesuai, 28,57 \% cukup sesuai, dan $66,07 \%$ sesuai. Sedangkan Rater 3 menyatakan komponen laman administrator $1,79 \%$ kurang sesuai, dan 98,21\% kompoten laman administrator sangat sesuai.

Tabel 7. Uji fungsionalitas laman Administrator oleh pengguna

\begin{tabular}{lccccc}
\hline Penilaian & Ordinal & Rater1 & Rater2 & Rater3 & Avg. \\
\hline Sangat & 5 & 96,43 & 0 & 98,21 & 64,88 \\
$\begin{array}{l}\text { Sesuai } \\
\text { Sesuai }\end{array}$ & 4 & 3,57 & 66,07 & 0 & 23,21 \\
$\begin{array}{l}\text { Cukup } \\
\text { Sesuai }\end{array}$ & 3 & 0 & 28,57 & 0 & 9,52 \\
$\begin{array}{l}\text { Kurang } \\
\text { Sesuai }\end{array}$ & 2 & 0 & 5,53 & 1,79 & 2,44 \\
$\begin{array}{l}\text { Tidak } \\
\text { Sesuai }\end{array}$ & 1 & 0 & 0 & 0 & 0,00 \\
\hline
\end{tabular}

\section{Uji T}

Sebelum dilakukan Uji T, terlebih dahulu dilakukan penyetaraan skala, yaitu penggabungan skala ordinal pada hasil uji oleh pengguna dan penyesuaian skor pada hasil uji dengan AppPerfect Web Test. Penggabungan ordinal "Kurang Sesuai" dan ordinal "Tidak Sesuai" digabungkan menjadi ordinal "Kurang/Tidak Sesuai" dengan menjumlahkan prosentase keduanya. Sehingga didapatkan skala yang sama sebagai berikut:

\begin{tabular}{lclc}
\multicolumn{2}{c}{ Tabel 8. Penyetaraan data hasil uji fungsionalitas sistem informasi } \\
\hline \multicolumn{2}{c}{ Uji AppPerfect Web Test } & \multicolumn{2}{c}{ Uji Pengguna } \\
\hline \multicolumn{1}{c}{ Penilaian } & Skor & \multicolumn{1}{c}{ Penilaian } & Skor \\
\hline Sangat Sesuai & 4 & Successful & 4 \\
Sesuai & 3 & Failed & 3 \\
Cukup Sesuai & 2 & Not Played & 2 \\
Kurang/Tidak Sesuai & 1 & Timed Out & 1 \\
\hline
\end{tabular}

Berdasarkan penyetaraan data di atas maka didapatkan data uji fungsi laman Asesi, laman Asesor dan laman Administrator. Adapun data hasil uji fungsi laman Asesi yang disetarakan adalah sebagai berikut:

Tabel 9. Hasil uji fungsionalitas laman Asesi dengan aplikasi AppPerfect Web Test

\begin{tabular}{lcc}
\hline \multicolumn{1}{c}{ Result } & Ordinal & Percent \\
\hline Successful & 4 & $99,35 \%$ \\
Failed & 3 & $0,65 \%$ \\
Timed Out & 2 & $0 \%$ \\
Not Played & 1 & $0 \%$ \\
\hline TOTAL & & $100,00 \%$ \\
\hline
\end{tabular}

Tabel 10. Hasil uji fungsionalitas laman Asesi oleh pengguna

\begin{tabular}{lcc}
\hline \multicolumn{1}{c}{ Penilaian } & Ordinal & Percent \\
\hline Sangat Sesuai & 4 & $53,90 \%$ \\
Sesuai & 3 & $30,85 \%$ \\
Cukup Sesuai & 2 & $13,12 \%$ \\
Kurang/ Tidak Sesuai & 1 & $2,13 \%$
\end{tabular}




\begin{tabular}{ccc}
\hline Penilaian & Ordinal & Percent \\
\hline TOTAL & & $100,00 \%$ \\
\hline
\end{tabular}

Tabel 15. Hasil uji T

\begin{tabular}{|c|c|c|c|c|c|c|c|c|c|c|}
\hline \multicolumn{11}{|c|}{ Independent Samples Test } \\
\hline & & \multicolumn{2}{|c|}{$\begin{array}{c}\text { Levene's Test for } \\
\text { Equality of } \\
\text { Variances }\end{array}$} & \multicolumn{7}{|c|}{ t-test for Equality of Means } \\
\hline & & \multirow{2}{*}{$\mathrm{F}$} & \multirow{2}{*}{ Sig. } & \multirow{2}{*}{$\mathrm{t}$} & \multirow{2}{*}{$\mathrm{df}$} & \multirow{2}{*}{$\begin{array}{l}\text { Sig. (2- } \\
\text { tailed) }\end{array}$} & \multirow{2}{*}{$\begin{array}{c}\text { Mean } \\
\text { Difference }\end{array}$} & \multirow{2}{*}{$\begin{array}{l}\text { Std. Error } \\
\text { Difference }\end{array}$} & \multicolumn{2}{|c|}{\begin{tabular}{|c|c|}
$\begin{array}{c}95 \% \text { Confidence Interval } \\
\text { of the Difference }\end{array}$ \\
\end{tabular}} \\
\hline & & & & & & & & & Lower & Upper \\
\hline \multirow[t]{2}{*}{$\begin{array}{l}\text { Nilai } \\
\text { Pengujian }\end{array}$} & $\begin{array}{l}\text { Equal variances } \\
\text { assumed }\end{array}$ & 5,875 & ,024 & ,000 & 22 & 1,000 &,- 00417 & 14,33334 & $-29,72970$ & 29,72136 \\
\hline & $\begin{array}{l}\text { Equal variances } \\
\text { not assumed }\end{array}$ & & & ,000 & 16,527 & 1,000 &,- 00417 & 14,33334 & $-30,31090$ & 30,30256 \\
\hline \multirow{3}{*}{\multicolumn{6}{|c|}{ Kemudian data uji fungsi laman }} & \multicolumn{3}{|c|}{ Penilaian } & \multicolumn{2}{|r|}{ Percent } \\
\hline & & & & & & \multirow{2}{*}{\multicolumn{3}{|c|}{$\begin{array}{l}\text { Cukup Sesuai } \\
\text { Kurang Sesuai }\end{array}$}} & 2 & $9,52 \%$ \\
\hline & & & & & & & & & 1 & $2,44 \%$ \\
\hline \multicolumn{6}{|c|}{$\begin{array}{l}\text { Tabel 11. Hasil uji fungsionalitas laman Asesor dengan aplikasi } \\
\text { AppPerfect Web Test }\end{array}$} & \multicolumn{3}{|c|}{ TOTAL } & & 100,00 \\
\hline
\end{tabular}

\begin{tabular}{lcc}
\hline \multicolumn{1}{c}{ Result } & Ordinal & Percent \\
\hline Successful & 4 & $95,76 \%$ \\
Failed & 3 & $1,88 \%$ \\
Timed Out & 2 & $1,88 \%$ \\
Not Played & 1 & $0,47 \%$ \\
\hline TOTAL & & $100,00 \%$ \\
\hline
\end{tabular}

Tabel 12. Hasil uji fungsionalitas laman Asesor oleh pengguna

\begin{tabular}{lcc}
\hline \multicolumn{1}{c}{ Penilaian } & Ordinal & Avg. \\
\hline Sangat Sesuai & 4 & $53,74 \%$ \\
Sesuai & 3 & $38,09 \%$ \\
Cukup Sesuai & 2 & $6,12 \%$ \\
Kurang/ Tidak Sesuai & 1 & $2,04 \%$ \\
\hline TOTAL & & $100,00 \%$ \\
\hline
\end{tabular}

Sedangkan data uji fungsi laman Administrator adalah sebagai berikut:

Tabel 13. Hasil uji fungsionalitas laman Administrator dengan aplikasi AppPerfect Web Test

\begin{tabular}{lcc}
\hline \multicolumn{1}{c}{ Result } & Ordinal & Percent \\
\hline Successful & 4 & $99,06 \%$ \\
Failed & 3 & $0,43 \%$ \\
Timed Out & 2 & $0,51 \%$ \\
Not Played & 1 & $0,00 \%$ \\
\hline TOTAL & & $100,00 \%$ \\
\hline
\end{tabular}

Tabel 14. Uji fungsionalitas laman Administrator oleh pengguna

\begin{tabular}{lcc}
\hline \multicolumn{1}{c}{ Penilaian } & Ordinal & Percent \\
\hline Sangat Sesuai & 4 & $64,88 \%$ \\
Sesuai & 3 & $23,21 \%$ \\
\hline
\end{tabular}

Selanjutnya pada sebelum Uji $\mathrm{T}$ ditentukan hipotesis sebagai berikut:

$\mathrm{H}_{0}=$ Terdapat persamaan antara uji dengan AppPerfect Web Test dan uji oleh pengguna; $\mathrm{H}_{1}=$ Terdapat perbedaan antara uji dengan AppPerfect Web Test dan uji oleh pengguna; Kemudian Berdasarkan hasil Uji T, didapatkan hasil sebagai berikut:

Berdasarkan hasil equal variance assumed di atas, nilai $\mathrm{F}$ sebesar 5,875 dengan probabilitas 0,024. Menurut Priyastama (2017: 99) apabila probabilitas $>0.05$ dalam uji Independent Sample $T$ Test, maka hipotesis diterima. Sehingga tidak terdapat angka pada $\mathrm{t}$ test. Artinya tidak ada perbedaan antara hasil uji fungsional dengan aplikasi AppPerfect Web Test dengan uji fungsional dengan pengguna.

\section{Pembahasan}

Berdasarkan hasil uji blackbox dengan aplikasi AppPerfect Web Test, aplikasi Sistem Informasi Lembaga Sertifikasi Profesi (LSP) Batik, secara teknis dapat dikatakan layak untuk digunakan. Namun masih perlu dilakukan uji terhadap

Uji Fungsionalitas (Blackbox Texting) Sistem Informasi Lembaga Sertifikasi... | 124 
pengguna yang sesungguhnya. Aplikasi AppPerfect Web Test cukup relevan untuk pengujian dengan mesin (komputer) dengan iterasi yang dapat disesuaikan.

Hasil pengujian dengan pengguna orang, ditujukan untuk mengetahui sejauh mana pengguna dapat memahami fungsi dan mengoperasikan aplikasi sistem informasi. Dengan kata lain bila pengguna menyatakan fungsi telah sesuai dengan apa yang dipahami oleh pengguna, maka fitur aplikasi telah berfungsi dengan baik.

\section{PENUTUP}

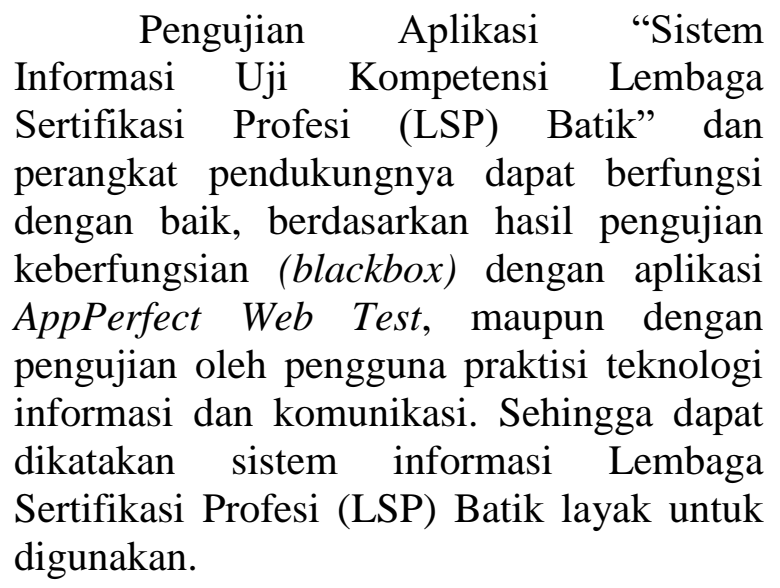

\section{DAFTAR PUSTAKA}

Appperfect.com. 2018. AppPerfect: Automated Web Functional Testing and Regression Testing. http://www.appperfect.com/products/ web-test.php, diakses tanggal 28 Agustus 2018.

BNSP RI. 2014. Peraturan Badan Nasional Sertifikasi Profesi Nomor 5/BNSP/VII/2014 tentang Pedoman Persyaratan Umum Tempat Uji Kompetensi. Jakarta: Badan Nasional Sertifikasi Profesi RI.
Dewi, R.S. 2018. "Analisis Dampak Integrasi Data terhadap Kecepatan Pelayanan Publik di Kota Surabaya". Jurnal Sistem Informasi, Vol. 14, No. 2, 2018, halaman 90-97. Jakarta: Universitas Indonesia. http://jsi.cs.ui.ac.id/index.php/jsi/arti cle/view/639, diakses tanggal 1 Desember 2018.

Hasan, D.N. \& Wijaya, M.S. 2016. "Storyboard in Teaching Writing Narrative Text". English Education: Jurnal Tadris Bahasa Inggris, Vol. 9, No. 2, September 2016, halaman 262275. Lampung: UIN Raden Intan Lampung.

http://ejournal.radenintan.ac.id/index .php/ENGEDU/article/view/372, diakses tanggal 5 Desember 2018.

Kemenperin RI. 2016. "Kemenperin Kembangkan Bahan Baku Alami Batik". Kementerian Perindustrian Republik Indonesia: Berita Industri. http://www.kemenperin.go.id/artikel/ 10141/Kemenperin-KembangkanBahan-Baku-Alami-Batik, diakses tanggal 20 Oktober 2017.

Lubis, I.K., Harjoko, A., \& Dewi, F.S.T. 2016. "Desain Sistem Pengingat Berbasis SMS untuk Meningkatkan Kepatuhan Pengobatan Pasien Diabetes Melitus". Journal of Information Systems for Public Health, Vol. 1, No. 1, April 2016, halaman 3-9. https://jurnal.ugm.ac.id/jisph/article/ view/7286, diakses tanggal 23 November 2018.

Pressman, R. S. 2001. Software Engineering: A Practitioner's Approach 5th Edition. New York : The McGrawHill Companies, Inc.

Priyastama, R. 2017. Buku Sakti Kuasai SPSS. Yogyakarta: Start Up. 
Purnomo, A.S. 2015. "Implementasi Google Maps API dengan PHP dan MySQL (Kasus: $\quad$ Sistem Informasi Pariwisata)". TEKNOIN, Vol. 21 No. 1 2015. http://journal.uii.ac.id/jurnalteknoin/article/view/3689, diakses tanggal 25 November 2018.

Simanjuntak, E.C., at al. 2010. "Blackbox Testing”. Kompasiana.com. 13 Desember 2010. http://www.kompasiana.com/elisa_gr ace_heriberty/ blackboxtesting_550051c7a333115b735107d b, diakses tanggal 15 Juni 2016.

Softwaretestinghelp.com. 2018. Black Box Testing: An In-depth Tutorial with
Examples and Techniques. https://www.softwaretestinghelp.com /black-box-testing/, diakses tanggal 25 Agustus 2018.

Sugiyono. 2015. Metode Penelitian Pendidikan (Pendekatan Kuantitatif, Kualitatif, dan $R \& D)$ ). Bandung: Alfabeta.

Wikipedia. 2012. Black-box testing. https://en.wikipedia.org/wiki/Blackbox_testing, diakses tanggal 22 Maret 2016.

Williams, L. 2010. A (Partial) Introduction to Software Engineering Practices and Methods. North Carolina : North Carolina State University. 